\title{
Pelatihan Pembuatan Media Pembelajaran Matematika Berbasis Flash Menggunakan Adobe Animate bagi Guru SMP di Kabupaten Kuningan
}

\author{
Uba Umbara ${ }^{1}$, Abdul Rosyid², Dena Latif Setiawan ${ }^{3}$ \\ 1, 2, 3 STKIP Muhammadiyah Kuningan
}

\begin{tabular}{l}
\hline Article History \\
\hline Received 11.11 .2018 \\
Received in revised form \\
01.12 .2018 \\
Accepted 31.03 .2019 \\
Available online 02.04 .2019
\end{tabular}

\begin{abstract}
TRAINING FOR MAKING FLASH-BASED MATHEMATICS LEARNING MEDIA USING ANIMATE ADOBE FOR SECONDARY SCHOOL TEACHERS IN KUNINGAN DISTRICT. The purpose of the community partnership program for MGMP teachers at the Kuningan Cluster and Luragung Clusters in Kuningan Regency is to improve teacher competency in creating, developing and implementing flash-based mathematics learning media using Adobe Animate. The problem faced by partners is in implementing mathematics learning in schools that are still dominated through the use of textbooks, so that the teacher's ability to demonstrate mathematical concepts in learning is still lacking. This was allegedly due to the limited ability of teachers to use learning media, especially ICT-based media. Mathematical MGMP SMP Kuningan cluster and Luragung cluster in Kuningan Regency have a sufficient number of teacher members, but in terms of competence still needs improvement. Understanding of computer-based learning is still very minimal because mathematics teachers have not received specific training on ICT-based mathematics learning. To overcome this condition an activity was packaged in the form of training on the development of flash-based mathematics learning devices using adobe animate for the mathematics MGMP of the Brass Cluster and Luragung Group. This activity was carried out through the following stages: 1) the provision of flash-based mathematics learning and development workshops using adobe animate; 2) mentoring in making flash-based mathematics learning devices using adobe animate; 3) mentoring implementation of flash-based mathematics learning devices using adobe animate; and 4) evaluation and replication.
\end{abstract}

Keywords: Adobe Animate, Mathematics Learning, Media Based on Flash, Training. 


\section{PENDAHULUAN}

Pendidikan merupakan proses alami dan memegang peranan penting dalam setiap kehidupan manusia. Pendidikan harus mampu mengakomodasi kebutuhan setiap insan pembelajar agar mempunyai kesiapan dalam menghadapi era baru yang penuh tantangan tidak pernah lepas dari tuntutan perubahan, sehingga pendidikan harus mampu mengembangkan potensi pembelajar agar mampu menghadapi tuntutan dan perubahan zaman yang dimaksudkan. Hal tersebut, sejalan dengan fungsi dari Pendidikan Nasional yang tercantum dalam Undang-undang Republik Indonesia Nomor 20 tahun 2003, yaitu mengembangkan kemampuan dan membentuk watak serta peradaban bangsa yang bermartabat dalam rangka mencerdaskan kehidupan bangsa. Peningkatan kualitas pendidikan merupakan langkah awal untuk meningkatkan sumber daya manusia suatu bangsa di era globalisasi dan ditengah kemajuan Iptek.

Prinsip pengembangan kurikulum 2013 seperti tercantum dalam Buku Materi Pelatihan Implementasi Kurikulum 2013 (Kemendikbud, 2014) poin ke 6 sampai ke 9 yakni.

1) Berpusat pada potensi, perkembangan, kebutuhan, dan kepentingan peserta didik dan lingkungannya. Kurikulum dikembangkan berdasarkan prinsip bahwa peserta didik berada pada posisi sentral dan aktif dalam belajar.

2) Kurikulum harus tanggap terhadap perkembangan ilmu pengetahuan, budaya, teknologi, dan seni.

3) Kurikulum harus relevan dengan kebutuhan kehidupan.

4) Kurikulum harus diarahkan kepada proses pengembangan, pembudayaan dan pemberdayaan peserta didik yang berlangsung sepanjang hayat.

Dari ke empat prinsip yang diuraikan di atas dapat diketahui bahwa kurikulum 2013 mengalami perubahan yang cukup progresif terhadap prinsip-prinsip pembelajaran dari kurikulum sebelumnya. Kurikulum 2013 ditandai dengan pengembangan kompetensi berupa sikap, pengetahuan, ketrampilan berpikir, ketrampilan psikomotorik yang dikemas secara terintegrasi dalam berbagai mata pelajaran secara komprehensif.Salah satu prinsip pada kurikulum 2013 yang menyatakan bahwa kurikulum harus tanggap terhadap perkembangan ilmu pengetahuan, budaya, teknologi dan seni harus menjadi titik tolak dalam pengembangan kurikulum. Dengan mencermati prinsip tersebut hendaknya harus didukung sebagai suatu upaya dalam memperbaiki proses pendidikan. Dalam kaitannya dengan pembelajaran matematika, maka kurikulum yang digunakan harus tanggap terhadap perkembangan ilmu pengetahuan dan teknologi dapat dimaknai sebagai suatu respon pendidikan terhadap perkembangan ilmu pengetahuan dan teknologi yang sangat pesat di era globalisasi yang begitu dinamis.

Hal tersebut dimaksudkan agar siswa mampu menghadapi tuntutan dan perubahan zaman di era teknologi dan informasi. Untuk itu, guru sebagai salah satu sumber keilmuan memberikan cara pandang terhadap matematika dan akan berpengaruh terhadap cara menyampaikan matematika kepadasiswa. Turmudi (2009) menyatakan bahwa pembelajaran matematika sebagai salah satu bidang keilmuan yang tidak terlepas dari adanya guru, siswa dan materi sebagai salah satu sumber bahan ajar. Guru senantiasa menjadi pusat perhatian karena ia harus mendemonstrasikan matematika yang siap saji. Guru yang mempunyai kemampuan dalam mendemonstrasikan kemampuan matematis tanpa buku di depan siswa, itulah guru yang luar biasa menurut pandangan ini. Hal ini berkesesuaian dengan Rumijan et al (2017) bahwa keterampilan pengembangan desain 
dan pembuatan media pembelajaran yang dimiliki guru akan menghasilkan benda yang dapat digunakan sebagai media pembelajaran yang dapat memungkinkan murid menjadi aktif, kreatif, dan menyenangkan dalam kegiatan belajarnya.

Pada umumnya di wilayah Kabupaten Kuningan pelaksanakan pembelajaran matematika di sekolah masih didominasi melalui penggunaan buku teks. Sehingga kemampuan guru dalam mendemonstrasikan konsep matematika dalam pembelajaran masih kurang.Hal tersebut disinyalir karena keterbatasan kemampuan guru dalam menggunakan media pembelajaran, khususnya media berbasis ICT. Kelompok guru yang masih belum mampu mengintegrasikan penggunaan teknologi informasi dan komunikasi khususya komputer dalam pembelajaran adalah MGMP Matematika SMP gugus Kuningan dan gugus Luragung Kabupaten Kuningan. MGMP Matematika SMP gugus Kuningan dan gugus Luragung Kabupaten Kuningan merupakan organisasi profesi yang mempunyai kerjasama dengan Prodi Pendidikan Matematika STKIP Muhammadiyah Kuningan.

Alasan mendasar dalam pengembangan pembelajaran berbasis komputer dalam pendidikan adalah untuk memudahkan siswa dan guru dalam melakukan pembelajaran matematika. Rusman (2013) menyatakan bahwa diantara pemanfaatannya adalah untuk kepentingan pembelajaran yaitu untuk membantu para guru dalam meningkatkan mutu pembelajaran. Terkait dengan hal tersebut dikenal dua bentuk pembelajaran yaitu: pembelajaran dengan bantuan komputer atau Computer Assisted Instruction (CAI) dan pembelajaran berbasis komputer atau Computer Based Instruction (CBI). Disamping itu perkembangan ilmu pengetahuan dan teknologi telah mendorong terciptanya kemudahan-kemudahan dalam mengakses informasi dan memperkecil waktu yang diperlukan untuk memperoleh pengetahuan tersebut, sehingga proses yang dibutuhkan untuk mencapai pemahaman terhadap suatu pelajaran dapat lebih cepat.

Suradijono (2004) dari studi-studi yang ada, pembelajaran berbasis komputer (courseware) bila dibuat dengan baik terbukti dapat meningkatkan proses belajar pada diri seseorang. Selanjutnya Sanjaya (2010) mengatakan bahwa dengan kemajuan teknologi, guru dapat menggunakan berbagai media sesuai dengan kebutuhan dan tujuan pembelajaran. Sejalan dengan Sanjaya, Peressini dan Knut (Jiang, 2008) menyatakan ada 5 hal dasar mengapa teknologi dipilih untuk digunakan sebagai alat pedagogis dalam pembelajaran matematika, yaitu:

1) Teknologi dapat digunakan untuk management. Dalam hal ini untuk memindahkan data pengetahuan atau arsip siswa dari bentuk buku ke dalam bentuk elektronik. Hal ini dimungkinkan untuk mempercepat proses pencarian arsip data siswa dan materi pembelajaran.

2) Teknologi dapat berperan sebagai alat komunikasi. Guru dan siswa dapat melakukan pembelajaran jarak jauh.

3) Teknologi dapat berperan sebagai alat evaluasi.

4) Teknologi dapat digunakan sebagai alat bantu memotivasi. Teknologi berupa komputer dapat melakukan pembelajaran yang berulang tanpa merasa bosan.

5) Pemanfaatan teknologi membantu pemahaman algoritma matematis siswa kepada arah yang lebih baik lagi, dapat meningkatkan keterampilan pemahaman konsep dan problem solving. Dalam kapasitas peningkatan kemampuan kognitif, teknologi menawarkan sesuatu yang unik untuk siswa yaitu memberikan kesempatan untuk melakukan eksplorasi terhadap konsep-konsep matematika. 
Beberapa program komputer dapat digunakan sebagai media pembelajaran yang interaktif dan dinamis.Media pembelajaran yang interaktif dan dinamis yaitu bahwa media tersebut dapat digunakan secara mandiri maupun kelompok serta media tersebut mampu memberikan pemahaman kepada penggunanya atas permasalahan matematika simbolik yang beraneka ragam (Marjuni, 2007). Dengan bantuan programnya komputer dapat memberi akses pada siswa untuk menganalisis dan mengeksplorasi konsep matematika, sehingga siswa memperoleh pemahaman yang lebih baik dalam konsep tersebut. Model yang dapat digunakan dalam pembelajaran berbasis komputer adalah model drill and practice, model tutorial, dan model instructional games.

MGMP Matematika SMP gugus Kuningan dan gugus Luragung Kabupaten Kuningan memiliki jumlah anggota guru yang secara kuantitaif telah mencukupi namun dari sisi kompetensi masih perlu peningkatan. Pemahaman tentang pembelajaran berbasis komputer masih sangat minim karena guru-guru matematika belum mendapatkan pelatihan khusus tentang pembelajaran matematika berbasis Flash. Salah satu kekuatan yang dimiliki kelompok guru ini adalah mereka semua berlatar belakang sarjana pendidikan matematika. Sisi lain adalah kelompok guru ini adalah mempunyai program kerja yang tersruktur dalam upaya peningkatan kompetensi guru matematika. Namun demikian guru belum difasilitasi secara optimal untuk membuat media pembelajaran berbasis ICT khususnya komputer secara mandiri.

Hasil diskusi dengan kedua ketua MGMP menyatakan bahwa bahwa proses pengajaran yang dilakukan oleh guru-guru terbatas pada sumber buku teks. Masih berdasarkan hasil evaluasi penelitian internal, juga diketahui bahwa para guru belum siap menjalankan pembelajaran matematika berbasis ICT karena kemampuan guru dalam membuat model pembelajaran berbasis ICT. Oleh karena itu kegiatan Pengabdian Program Kemitraan Masyarakat (PKM) ini dimaksudkan untuk menyiapkan guru SMP khususnya yang tergabung dalam MGMP Matematika gugus Kuningan dalam membuat dan mengimplementasikan perangkat pembelajaran berbasis Flash. Berdasarkan hal tersebut maka dalam PKM ini akan difokuskan pada workshop perencanaan proses pembelajaran, pengembangan perangkat pembelajaran matematika berbasis Flash, pendampingan implementasi perangkat pembelajaran. Sehingga kegiatan PKM diharapkan mampu membantu guru dalam mengimplementasikan pembelajaran berbasis IT.

\section{METODE PELAKSANAAN}

Kegiatan pengabdian masyarakat ini dilakukan dengan metode pelatihan. Metode yang digunakan dalam kegiatan ini adalah Model B (Pendampingan) dan metode pelaksanaa kegiatan ini metoda II (Pendampingan), yaitu: pelatihan dalam bentuk penyajian materi pelatihan dan penugasan untuk bentuk membuat media (Sriyanti et al, 2015). Evaluasi dilakukan pada akhir kegiatan berupa wawancara dan angket. Indikator pencapaian tujuan apabila sekurang-kurangnya $80 \%$ dari khalayak sasaran dapat melaksanakannya.

Khalayak sasaran dalam program pengabdian ini adalah guru anggota MGMP Matematika SMP gugus Kuningan dan gugus Luragung Kabupaten Kuningan dengan jumlah peserta sebanyak 46 orang guru. Kegiatan pengabdian ini dilakukan di sekretariat MGMP Matematika SMP gugus Kuningan yang berada di SMP Negeri 5 Kuningan yang 
beralamat di Jl. Siliwangi No. 74 Kuningan 45512 dan sekretariat MGMP Matematika SMP gugus Luragung Kabupaten Kuningan yang berada di SMP Negeri 1 Luragung yang beralamat di Jl. Raya Luragung - Kuningan Desa Sindangsuka Kecamatan Luragung Kabupaten Kuningan.

Oleh karena itu kegiatan melakukan pendampingan dalam membuat dan mengimplementasikan perangkat pembelajaran matematika berbasis Flash yang dilakukan melalui tahapan: (1) pemberian workshop pembuatan dan pengembangan perangkat pembelajaran matematika berbasis Flash menggunakan Adobe Animate; (2) pendampingan pembuatan perangkat pembelajaran matematika berbasis Flash menggunakan Adobe Animate; (3) pendampingan implementasi perangkat pembelajaran matematika berbasis Flash menggunakan Adobe Animate dan (4) evaluasi dan repleksi.

Alur pelaksanaan kegiatan PKM pengembangan perangkat pembelajaran berbasis berbasis Flash bagi MGMP Matematika gugus Kuningan dan gugus Luragung Kabupaten Kuningan adalah sebagai berikut.

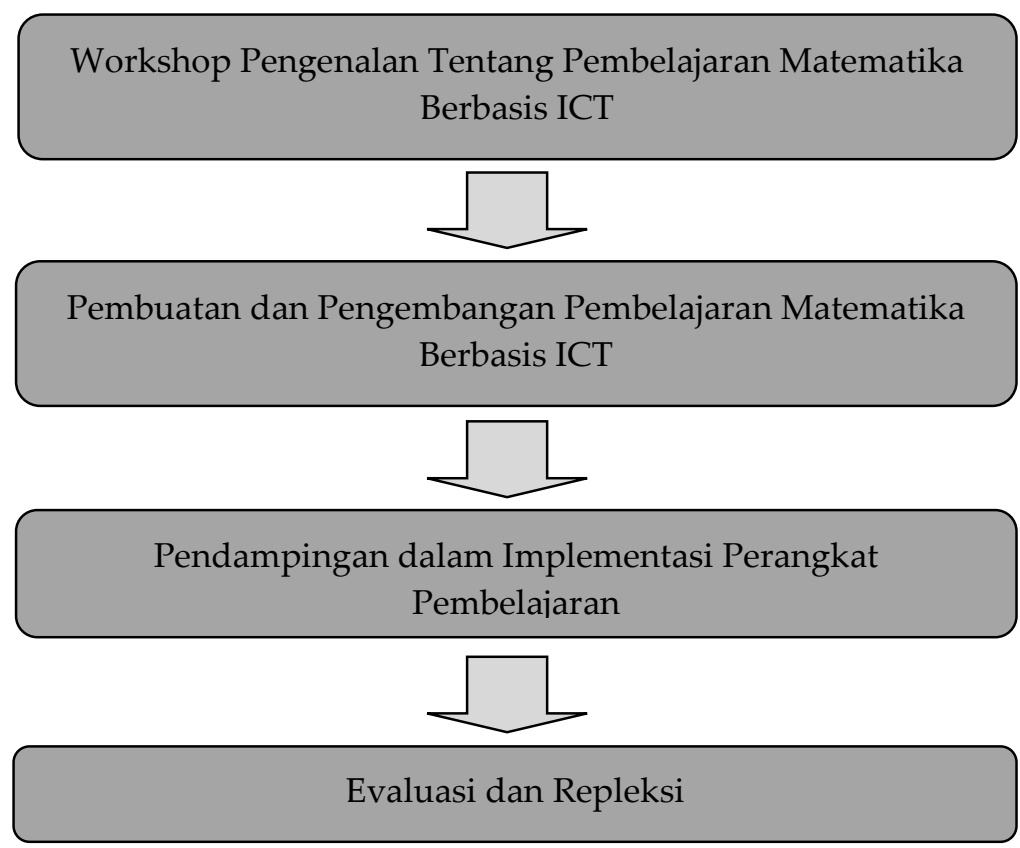

Gambar 1. Alur Kegiatan Pelatihan

Berikut ini merupakan penjabaran kegiatan tim pengabdian dan guru yang tergabung dalam MGMP Matematika gugus Kuningan dan gugus Luragung Kabupaten Kuningan berdasarkan alur pelaksanaan kegiatan PKM pengembangan perangkat pembelajaran berbasis berbasis Flash.

\section{Workshop Pengenalan Tentang Pembelajaran Matematika Berbasis berbasis Flash}

Tim Pengabdi

Kegiatan yang dilakukan di sekretariat kedua gugus MGMP Matematika diawali dengan proses sosialisasi program pengabdian. Kemudian dilanjutkan dengan pemberian materi tentangpengembangan perangkat pembelajaran berbasis IT.Setelah pemberian materi, peserta diminta untuk melakukan analisis kebutuhan, meliputi analisis karakteristik siswa, analisis implementasi kurikulum yang dilaksanakan, analisis materi, ketersediaan bahan, kesediaan sarana dan prasarana penunjang pembelajaran berbasis komputer yang dimiliki oleh guru maupun sekolah. Analisis ini diperlukan untuk 
mengetahui jenis mediadan modelpembelajaran matematika berasis komputer yang akan cocok untuk dikembangkan di masing-masing sekolah. Pada akhir kegiatan diharapkan peserta mampu menentukan materi yang akan dibuat beserta jenis model pembelajaran berbasis komputer yang akan dikembangkan.

Guru-guru MGMP Matematika gugus Kuningandan gugus Luragung Kabupaten Kuningan

Menghadiri acara workshop yang dilaksanakan di sekretariat keuda MGMP Matematika diawali dengan proses sosialisasi program pengabdian. Kegiatan diawali dengan sosialisasi program pengabdian dan dilanjutkan dengan materi tentangpengembangan perangkat pembelajaran berbasis berbasis IT. Adapun materi yang harus dipahami adalah mengenai pembuatan perangkat pembelajaran berbasis komputer serta pentingnya penggunaannya dalam proses pembelajaran. Diantara model pembelajaran berbasis IT dengan menggunakan program adobe Flash dengan menggunakan jenis Adobe Animate yang disosialisaikan adalah model drill and practice, model tutorial, dan model instructional games.Selanjutnya, melakukan analisis karakteristik siswa, analisis implementasi kurikulum yang dilaksanakan, analisis materi, ketersediaan bahan, kesediaan sarana dan prasarana penunjang pembelajaran berbasis komputer yang dimiliki oleh guru maupun sekolah. Analisis ini diperlukan untuk mengetahui jenis mediadan modelpembelajaran matematika berasis komputer yang akan cocok untuk dikembangkan di masing-masing sekolah. Dengan analisis ini, guru menentukan modelpembelajaran berbasis berbasis Flash yang akan dibuat dan dikembangkan yang akan menjadi prioritas utama.

\section{Pembuatan Dan Pengembangan Pembelajaran Matematika Berbasis berbasis Flash}

\section{Tim Pengabdi}

Menyediakan modul dan membimbing pembuatan dan pengembangan pembelajaran matematika berbasis Flash dengan model drill and practice, model tutorial, dan model instructional games dengan menyediakan flow chart berupa alur dalam bentuk kotak-kotak dialog yang memiliki makna dan arti tersendiri.

Guru-guru MGMP Matematika gugus Kuningan dan gugus Luragung Kabupaten Kuningan

Dengan didampingi oleh tim pendamping guru membuat dan mengembangkan pembelajaran matematika berbasis Flash dengan model drill and practice, model tutorial, dan model instructional games sesuai dengan materi yang dipilih oleh guru berdasarkan hasil analisis sebelumnya.

\section{Pendampingan Dalam Implementasi Perangkat Pembelajaran}

Tim Pengabdi

Perangkat pembelajaran yang telah dibuat diimplementasikan pada pembelajaran di kelas pada masing-masing sekolah. Saat pembelajaran, guru didampingi oleh timpengabdian. Akhir pembelajaran, tim pengabdian dan guru mengevaluasi bersamasama terrhadap efektivitas pelaksanaan perangkat pembelajaran di kelas.

\section{Guru-guru MGMP Matematika gugus Kuningan dan gugus Luragung Kabupaten Kuningan}

Melaksanakan proses pembelajaran dengan menggunakan perangkat pembelajaran yang telah disepakati.

\section{Evaluasi dan Repleksi}

Pada tahap ini dilakukan evaluasi terhadap efektivitas perangkat pembelajaran yang telah diimplementasikan dalam proses pembelajaran di kelas. Pada kegiatan ini juga dilaksanakan refleksi terhadap seluruh kegiatan yang telah dilaksanakan. Refleksi diawali 
dengan pengisian angket, tanya jawab dan diskusi dengan guru sebagai bahan pertimbangan atau rekomendasi pada kegiatan selanjutnya.

Adapun indikator luaran dari program pelatihan ini ini dapat dilihat dalam Tabel 1.

Tabel 1. Indikator Luaran Program

\begin{tabular}{|c|c|c|c|}
\hline No. & Target & Metode & Luaran \\
\hline 1. & $\begin{array}{l}\text { Peningkatan pemahaman guru } \\
\text { Matematika yang tergabung } \\
\text { dalam MGMP matematika gugus } \\
\text { Kuningan dan gugus Luragung } \\
\text { Kabupaten Kuningan terhadap } \\
\text { pembelajaran matematika berbasis } \\
\text { Flash. }\end{array}$ & $\begin{array}{l}\text { Workshop } \\
\text { brainstorming, } \\
\text { diskusi dan ceramah }\end{array}$ & $\begin{array}{l}\text { Perangkat } \\
\text { Pembelajaran } \\
\text { matematika } \\
\text { berbasis Flash. }\end{array}$ \\
\hline 2. & $\begin{array}{l}\text { Peningkatan kompetensi guru } \\
\text { Matematika yang tergabung } \\
\text { dalam MGMP matematika gugus } \\
\text { Kuningan dan gugus Luragung } \\
\text { Kabupaten Kuningan dalam } \\
\text { pembuatan dan pengembangan } \\
\text { perangkat pembelajaraan } \\
\text { matematika berbasis Flash dengan } \\
\text { model drill and practice, model } \\
\text { tutorial, dan model instructional } \\
\text { games. }\end{array}$ & $\begin{array}{l}\text { Pendampingan dan } \\
\text { diskusi }\end{array}$ & $\begin{array}{l}\text { Perangkat } \\
\text { Pembelajaran } \\
\text { matematika } \\
\text { berbasis Flash } \\
\text { dengan model drill } \\
\text { and practice, model } \\
\text { tutorial, dan } \\
\text { model } \\
\text { instructional } \\
\text { games. }\end{array}$ \\
\hline 3. & $\begin{array}{l}\text { Peningkatan kompetensi guru } \\
\text { Matematika yang tergabung } \\
\text { dalam MGMP matematika gugus } \\
\text { Kuningan dan gugus Luragung } \\
\text { Kabupaten Kuningan dalam } \\
\text { implementasi pembelajaraan } \\
\text { matematika berbasis Flash. }\end{array}$ & $\begin{array}{l}\text { Pendampingan dan } \\
\text { kolaborasi }\end{array}$ & $\begin{array}{l}\text { Rekaman } \\
\text { pemanfaatan } \\
\text { perangkat } \\
\text { pembelajaran } \\
\text { matematika }\end{array}$ \\
\hline
\end{tabular}

\section{HASIL DAN PEMBAHASAN}

Pelaksanaan kegiatan pengabdian yang dilakukan oleh tim dosen dari prodi pendidikan matematika dan prodi pendidikan teknologi dan ilmu komputer selama kurang lebih 3 bulan, dari bulan Agustus 2018 hingga Oktober 2018. Program pengabdian ini terbagi menjadi 6 sesi, dengan kegiatan masing-masing sesi sebagai berikut:

\section{Sesi 1}

Sesi 1 dilaksanakan pada hari Jum'at tanggal 31 Agustus 2018, bertempat di Aula STKIP Muhammadiyah Kuningan. Materi pelatihan yang disampaikan pada sesi ini adalah Media pembelajaran matematika dan Media pembelajaran berbasis ICT. Pelaksanaan kegiatan dapat dilihat pada Gambar 2. 


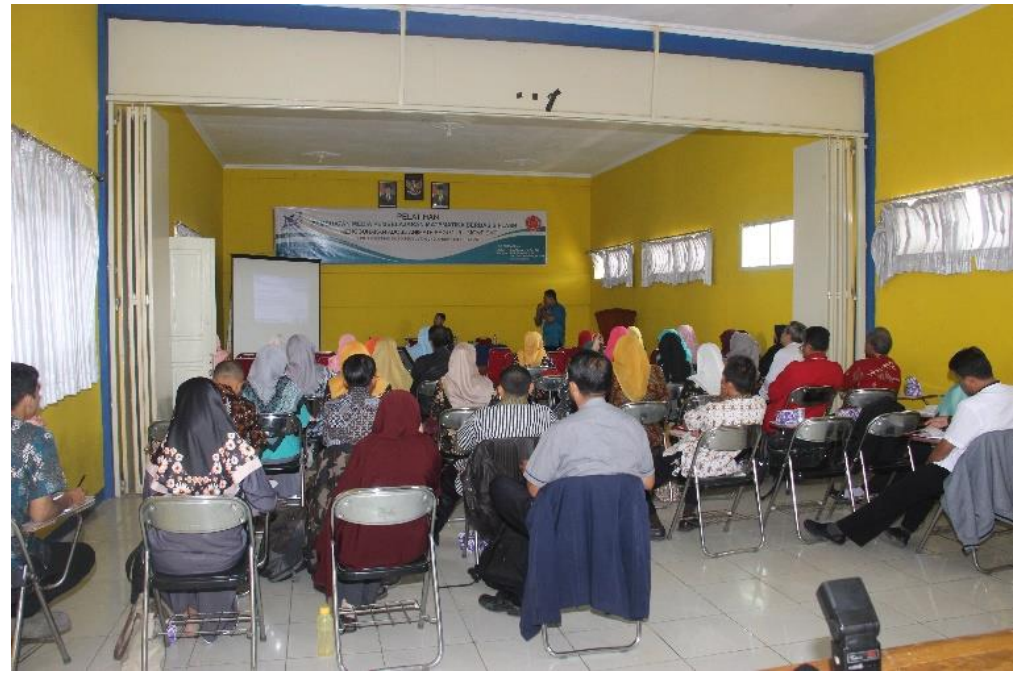

Gambar 2. Kegiatan Pelatihan Sesi 1

\section{Sesi 2}

Sesi 2 dilaksanakan pada hari Sabtu tanggal 15 September 2018, bertempat di sekretariat MGMP Matematika SMP gugus Luragung. Materi pelatihan yang disampaikan pada sesi ini adalah model-model media pembelajaran berbasis ICT dan teknik pemilihan materi dalam pembuatan media pembelajaran matematika berbasis ICT. Pelaksanaan kegiatan dapat dilihat pada gambar 3 berikut ini.

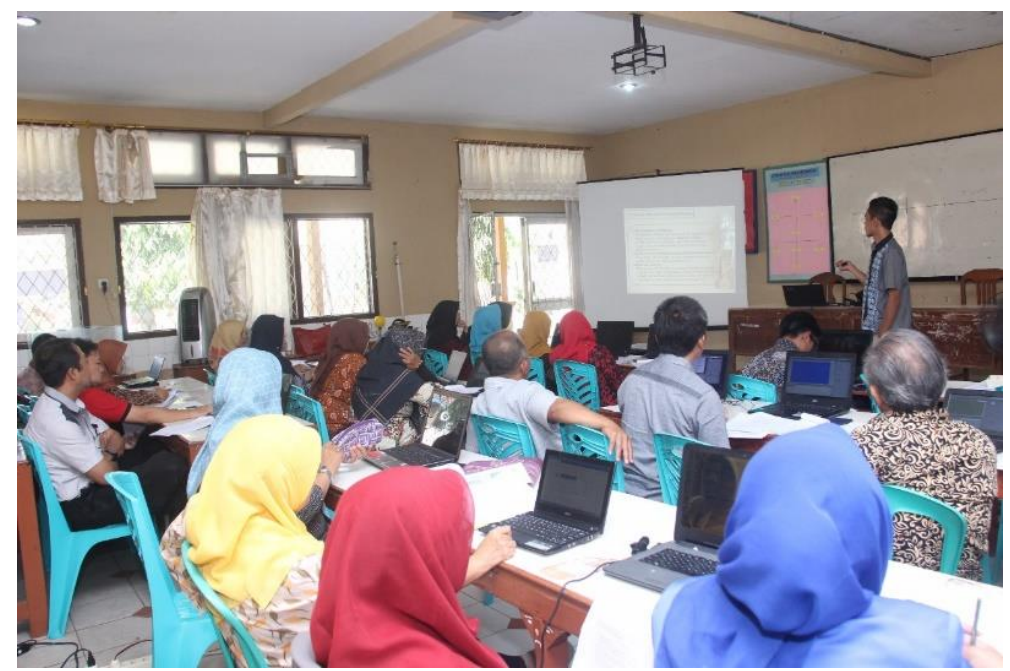

Gambar 3. Kegiatan Pelatihan Sesi 2

Sesi 3

Sesi 3 dilaksanakan pada hari Sabtu tanggal 22 September 2018, bertempat di sekretariat MGMP Matematika SMP gugus Kuningan Kota. Materi pelatihan yang disampaikan pada sesi ini adalah teknik mengembangkan media pembelajaran matematika model drill and practice, Demontrasi pembuatan media pembelajaran matematika model drill and practice dan Pendampingan pembuatan flow chart dan story board media pembelajaran matematika model drill and practice. Pelaksanaan kegiatan dapat dilihat pada Gambar 4. 


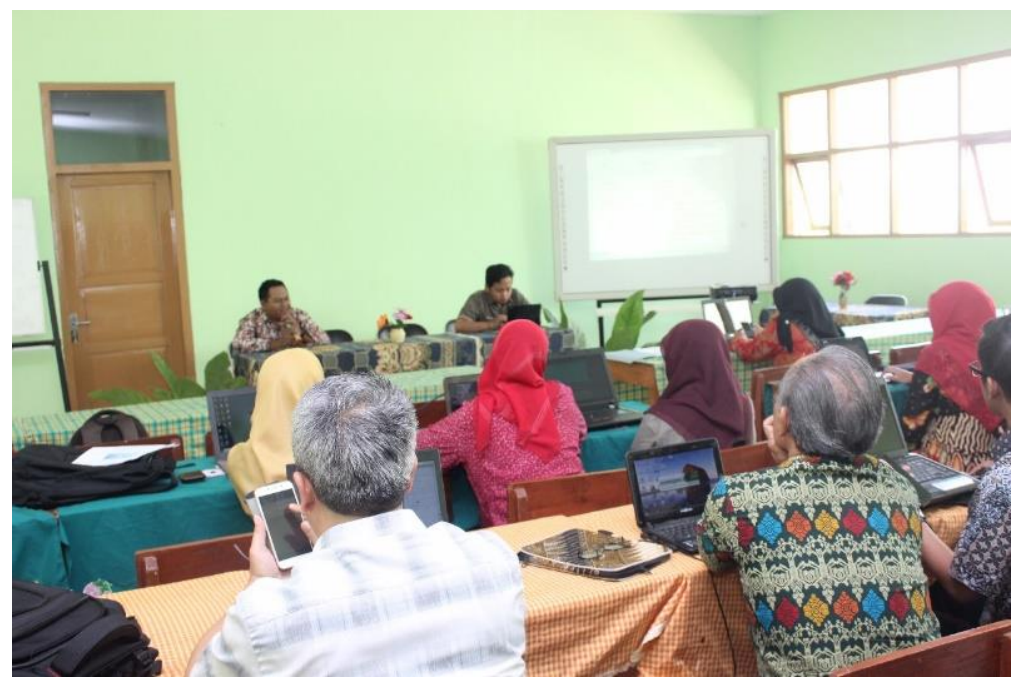

Gambar 4. Kegiatan Pelatihan Sesi 3

\section{Sesi 4}

Sesi 4 dilaksanakan pada hari Sabtu tanggal 29 September 2018, bertempat di sekretariat MGMP Matematika SMP gugus Luragung. Materi pelatihan yang disampaikan pada sesi ini adalah teknik mengembangkan media pembelajaran matematika model tutorial, demontrasi pembuatan media pembelajaran matematika model tutorial dan pendampingan pembuatan flow chart dan story board media pembelajaran matematika model tutorial. Pelaksanaan kegiatan dapat dilihat pada Gambar 5.

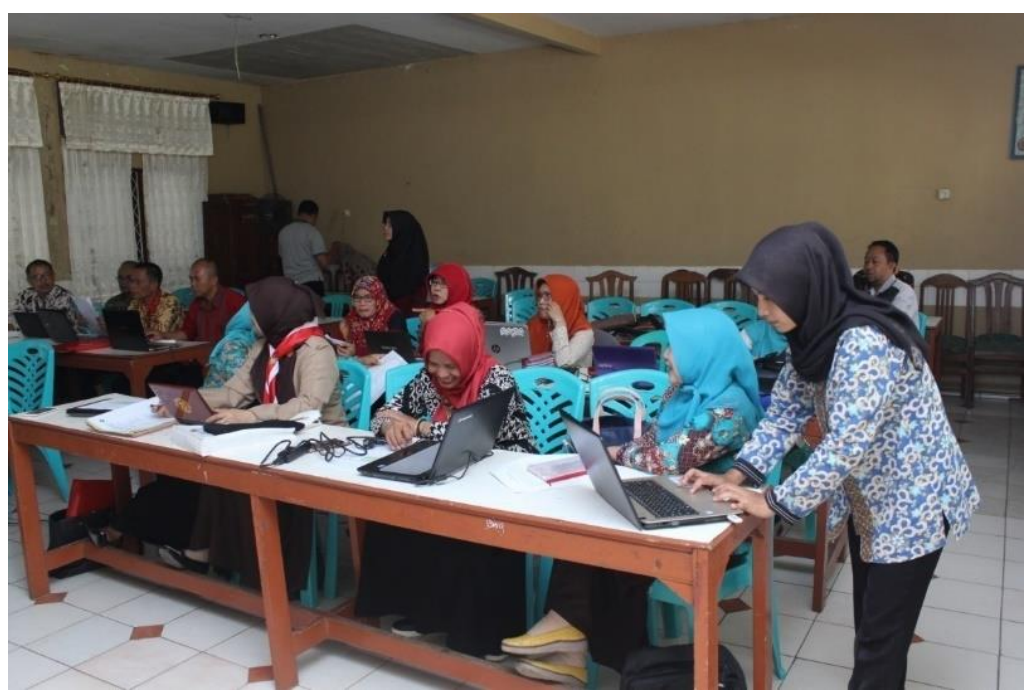

Gambar 5. Kegiatan Pelatihan Sesi 4

\section{Sesi 5}

Sesi 5 dilaksanakan pada hari Sabtu tanggal 6 Oktober 2018, bertempat di sekretariat MGMP Matematika SMP gugus Kuningan Kota. Materi pelatihan yang disampaikan pada sesi ini adalah teknik mengembangkan media pembelajaran matematika model instructional games, demontrasi pembuatan media pembelajaran matematika model instructional games dan pendampingan pembuatan flow chart dan story board media pembelajaran matematika model instructional games. Pelaksanaan kegiatan dapat dilihat pada Gambar 6. 


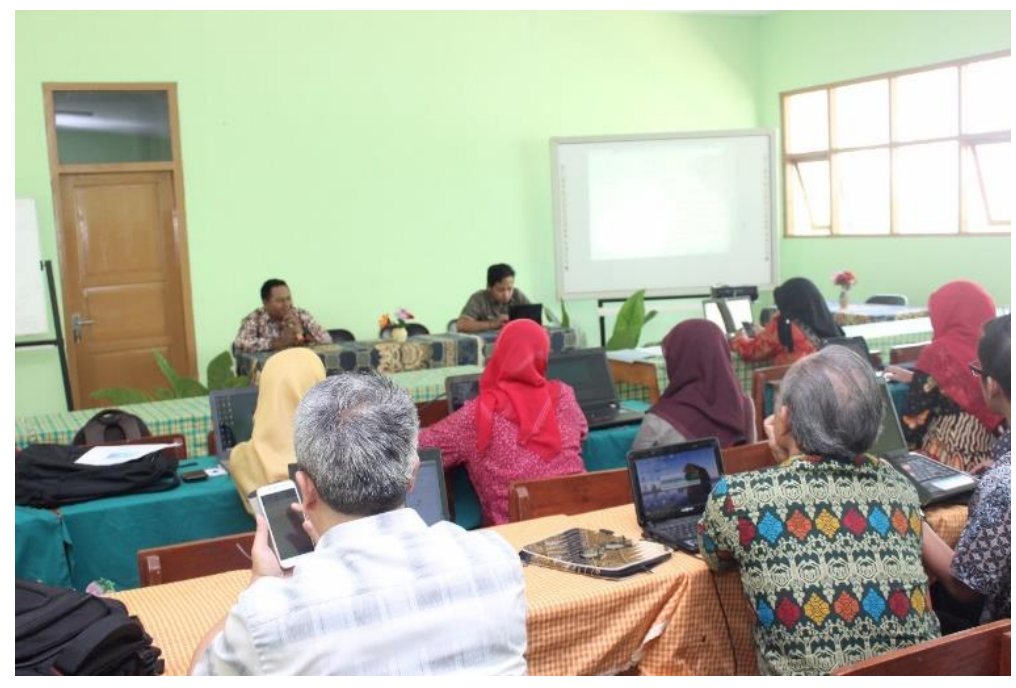

Gambar 6. Kegiatan Pelatihan Sesi 5

\section{Sesi 6}

Sesi 6 dilaksanakan pada hari Selasa tanggal 16 Oktober 2018, bertempat di SMP Negeri 1 Kuningan. Kegiatan pelatihan yang disampaikan pada sesi ini adalah pendampingan implementasi media Pembelajaran matematika berbasis ICT dan evaluasi dan repleksi pembuatan, pengembangan dan implementasi media pembelajaran matematika berbasis ICT dalam pembelajaran matematika. Pelaksanaan kegiatan dapat dilihat pada Gambar 7.

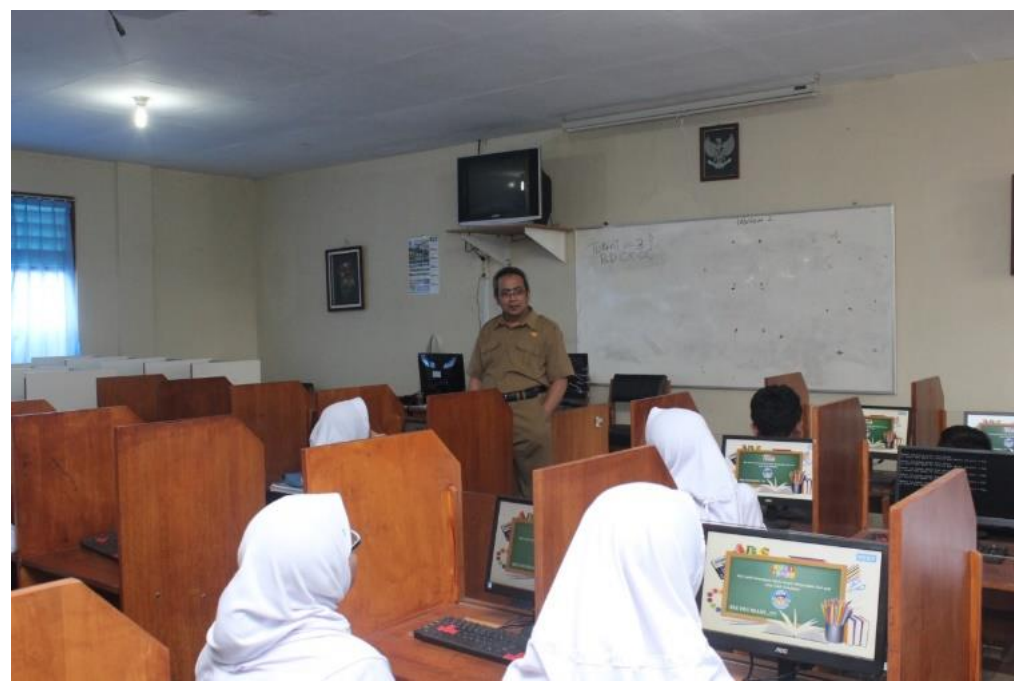

Gambar 7. Kegiatan Pelatihan Sesi 6

Beberapa hasil yang telah dicapai dalam Kegiatan Program Kemitraan Masyarakat (PKM) ini belum adalah sebagai berikut:

1) Meningkatnya pengetahuan dan pemahaman guru berkenaan dengan penggunaan media pembelajaran matematika berbasis ICT khusunya melalui penggunaan media pembelajaran matematika berbasis Flash menggunakan Adobe Animate. Sebagaimana telah dipaparkan sebelumnya bahwa kegiatan ini bertujuan membekali guru untuk memahami penggunaan media pembelajaran matematika berbasis Flash 
menggunakan Adobe Animate dengan harapan dapat menerapkan dalam pembelajaran di kelas.

2) Meningkatnya kemampuan guru dalam membuat perencanaan pembelajaran khususnya dalam merencanakan penggunaan media pembelajaran matematika berbasis ICT khusunya melalui penggunaan media pembelajaran matematika berbasis Flash menggunakan Adobe Animate. Media pembelajaran matematika berbasis Flash menggunakan Adobe Animate dapat digunakan salah satu alternatif variasi pembelajaran sebagai upaya untuk meningkatkan kemampuan matematis siswa.

3) Selama proses pelatihan $95 \%$ peserta pelatihan memiliki antusiasme yang tinggi untuk ikut serta dalam mengembangkan media pembelajaran matematika berbasis Flash menggunakan Adobe Animate. Kendala yang dialami selama pelatihan adalah 5\% peserta belum terbiasa menggunakan media komputer.

4) Setelah proses pelatihan dan pendampingan selesai dilaksanakan sampai sesi 5, 90\% guru mampu membuat minimal satu model media pembelajaran matematika berbasis Flash menggunakan Adobe Animate.

5) Pada proses pendampingan implementasi media pembelajaran matematika berbasis Flash menggunakan Adobe Animate, siswa terlihat begitu antusias dalam mengikuti pembelajaran. Pembelajaran berbantuan komputer telah dapat memberikan nuansa yang berbeda dalam pembelajaran dalam rangka meningkatkan prestasi belajar dan motivasi (Jauhari, 2009). Dari hasil postes setelah pembelajaran,siswa yang dinyatakan tuntas sebesar $90 \%$ siswa.

6) Dari hasil evaluasi dan repleksi yang dilakukan bersama-sama antara tim pengabdian dan peserta pelatihan menghasilkan beberapa hal, yaitu: a) Penelitian akan lebih efektif jika dilakukan dengan pola pendampingan yang simultan; b) Media pembelajaran matematika berbasis Flash menggunakan Adobe Animate efektif digunakan dalam pembelajaran; c) Pembuatan media pembelajaran matematika berbasis Flash menggunakan Adobe Animate membutuhkan perencanaan yang matang dan waktu yang cukup lama untuk mengembangkannya namun media ini dapat digunakan berkali-kali tanpa khawatir terjadi kerusakan seperti media konvensional yang lainnya. Selanjutnya, media pembelajaran matematika berbasis Flash menggunakan Adobe Animate dapat digunakan oleh siswa kapanpun dan dimanapun.

\section{SIMPULAN}

Berdasarkan hasil kegiatan pelatihan dapat disimpulkan bahwa variasi pembelajaran matematika dapat dilakukan melalui penggunaan media pembelajaran matematika berbasis Flash menggunakan Adobe Animate. Antusiasme peserta yang merupakan anggota MGMP Matematika SMP Gugus Kuningan dan Gugus Luragung Kabupaten Kuningan sangat tinggi, sehingga mereka mampu membuat dan mengembangkan media pembelajaran matematika berbasis Flash menggunakan Adobe Animate diakhir pelatihan.

\section{Ucapan Terima Kasih}

Terima kasih kepada DRPM Kemenristekdikti yang telah memberikan hibah melalui skema Program Kemitraan Masyarakat (PKM), Segenap unsur pimpinan STKIP 
Muhammadiyah Kuningan, para pihak yang telah membantu penulisan karya tulis ilmiah ini, terutama kepada para penulis sebelumnya yang terdapat di dalam daftar pustaka (nama-nama peneliti yang terdapat di referensi) atas publikasi ilmiah sebelumnya yang diterbitkan dan disediakan secara terbuka (open source), dan juga reviewer dan editor dari jurnal ini, sehingga kami dapat mempublikasikan topik ini.

\section{REFERENSI}

Jauhari, J. (2009). Studi Terhadap Penggunaan Multimedia Interaktif dalam Pembelajaran MIPA di Indonesia. In Prosiding Seminar Nasional Penelitian, Pendidikan dan Penerapan MIPA. Fakultas MIPA UNY, Yogyakarta, 16 May 2009 (pp. 425-432). Yogyakarta: UNY.

Jiang, Z. (2008). Explorations and reasoning in the dynamic geometry environment. In the Proceedings of the Thirteenth Asian Conference on Computers in Education. Bangkok, Thailand: ACTM.

Kementerian Pendidikan dan Kebudayaan (2014). Materi pelatihan implementasi kurikulum 2013. Jakarta: Badan Pengembangan Sumber Daya Manusia Pendidikan dan Kebudayaan dan Penjaminan Mutu Pendidikan Kementerian Pendidikan dan Kebudayaan.

Marjuni, A. (2007). Media pembelajaran matematika dengan maple. Yogyakarta: Graha Ilmu.

Rumidjan, Sumanto, Sukamti, \& Sugiharti. (2017). Pelatihan pembuatan media pembelajaran untuk meningkatkan kualitas pembelajaran bagi guru sekolah dasar. Abdimas Pedagogi, 1(1), 77-81.

Rusman. (2013). Belajar dan pembelajaran berbasis komputer (Mengembangkan profesionalisme guru abad 21). Bandung: Alfabeta.

Sanjaya, W. (2010). Perencanaan dan desain sistem pembelajaran. Jakarta: Kencana Prenada Media Group.

Sriyanti, I., Murniati, M. M., \& Yusuf, M. (2015). Pelatihan pembuatan media pembelajaran berbasis e-learning bagi guru SMA Srijaya Negara Palembang. Jurnal Inovasi dan Pembelajaran Fisika, 2(1), 12-18.

Suradijono, S. H. R. (2004). Pembelajaran berbasis web: Suatu tinjauan dari aspek kognitif. In Lokakarya Metode Pembelajaran Berbasis Web. Departemen Teknik Penerbangan ITB, Bandung, October 1, 2004.

Turmudi. (2009). Taktik dan strategi pembelajaran matematika, referensi untuk guru matematika SMP/MA, mahasiswa, dan umum. Jakarta: Leuser Cita Pustaka. 